\title{
Novel EBG Structure BPF for UWB system
}

\author{
D. Sridhar raja , B. Kalaiselvi, T. Vijayan
}

\begin{abstract}
This paper discuses about application of Electro Magnetic Band-gap structure(EBG) application in design of microstrip band bass filter(BPF) in ultra wide band $(\mathrm{UWB})$ frequency. Here to obtain improved pass-band region and good out of band region a single Electro Magnetic Band-gap structure (EBG) cell is used. The simulation of the filter is done using advanced design system software (ADS), the obtained result is satisfactory in addition to the performance of the filter the size of overall filter is reduced in size which can be used in many compact handheld devices. [19],[20],[21]
\end{abstract}

Keywords : Band-pass filter, electromagnetic band-gap (EBG), ultra wideband (UWB), wideband filter.

\section{INTRODUCTION}

In present day correspondence frameworks ultra wide band (UWB) recurrence is utilized progressively due to in wide band nature application in transmission and getting information for its speed. This is because of the consent conceded by Federal Communications Commission (FCC) recurrence band 3.1 to $10.6 \mathrm{GHz}$ for business correspondence applications in February 2002[1].therefore in any correspondence framework band pass channel assumes a significant job, likewise structuring a conservative band pass channel turns out to be additionally encouraging are in remote minimal handheld gadgets. The other fundamental parameters taken to thought in structuring a band-pass channel are low addition misfortune over the whole pass band recurrence which is 3.1 to $10.6 \mathrm{GHz}$ and great return misfortune in stop band recurrence. Over numerous years numerous new techniques had been actualized in acquiring the previously mentioned parameter.in this strategy UWB channel present deceptive band, this undesired false groups is a noteworthy burden in execution of channel in pass band area. [2 ], [4],[6]

Currently Electromagnetic band-gap structures (EBG) are designed for application of filter design and other application in communication systems.. EBG structure has the unique property of suppression of propagating surface waves in micro strip device. Also the property of high impedance in suppressing surface waves in particular frequency it is more suitable for UWB -band-pass filter design. [14],[ 16], [18]

\section{Filter THEORY}

In planning any channel, beneath referenced are significant parameters

\section{Pass data transfer capacity}

Revised Manuscript Received on August 22, 2019.

Sridhar Raja D Department of EIE, Bharath Institute of Higher Education and Research, Tamilnadu, India. Email: sridharraja.eie@bharathuniv.ac.in

B.Kalaiselvi, Department of EIE, Bharath Institute of Higher education and research, Tamilnadu, India. Email: kalaiselvi.eie@bharathuniv.ac.in

T.Vijayan, Department of EIE,Bharath Institute of Higher education and research, Tamilnadu, India. Email: vijayan.eie@bharathuniv.ac.in

\section{Stop band constriction and frequencies}

3. Input and yield impedances

4. Return misfortune

\section{Insertion misfortune}

6. Group postponement

The parameters in over the abundancy reaction given as far as the addition misfortune Vs recurrence attributes are considered in reenactment. [1],[3],[5]

\section{Proposed EbG Structure.}

The electromagnetic band-hole (EBG), structure has a wide band-hole in nature. The inductor $\mathrm{L}$ is because of the present coursing through the associated by means of. The hole between conductor sides of two adjoining cells offers ascend to equal capacitance $\mathrm{C}$. This two dimensional occasional LC system is acquired, which results to recurrence band-hole and the inside recurrence of band-hole to decide utilizing recipe $\omega=1 / \sqrt{ } \mathrm{LC}$

From condition it demonstrates that so as to accomplish progressively reduced electromagnetic band-hole (EBG), structure, its capacitance $\mathrm{C}$ and inductance $\mathrm{L}$ ought to is expanded. In the EBG structure strategy, the inductance L can't changed if thickness of dielectric and type dielectric material is picked. The main strategy is to build the estimation of the capacitance C. [13], [15] ,[ 17]

Figure.1 below shows the proposed electromagnetic band-gap (EBG),

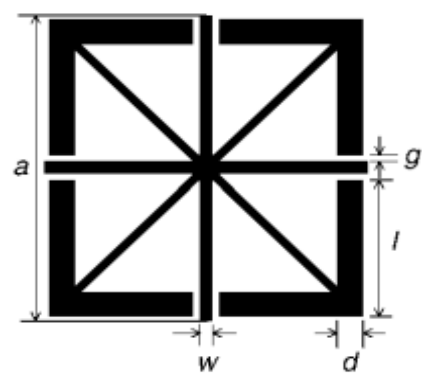

Fig 1.Proposed EBG structures

IV. THE PROPOSED ELECTROMAGNETIC BAND-GAP (EBG), UWB FILTERS 
The proposed UWB band pass channel is structured and reenacted utilizing ADS reproduction programming. The band pass channel is planned with thickness $0.635 \mathrm{~mm}$ on a RT/Duroid substrate which has the dielectric steady 10.2. The schematics of uni-planar minimal EBG (UC-EBG) structure are appeared in fig 2. The inside recurrence of $6.85 \mathrm{GHz}$ is gotten by the bury computerized coupled lines. [8],[ 10] ,[12]

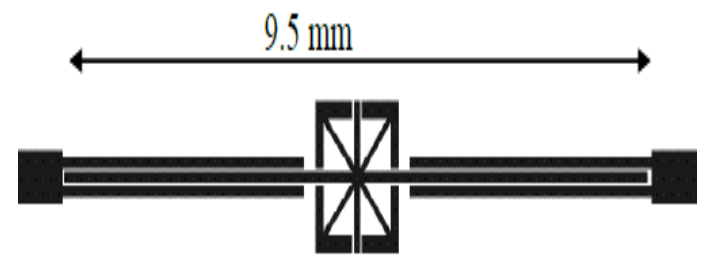

Fig.2 (a).EBG Embedded Multi Mode Resonator BPF

\section{SIMULATION RESULTS}
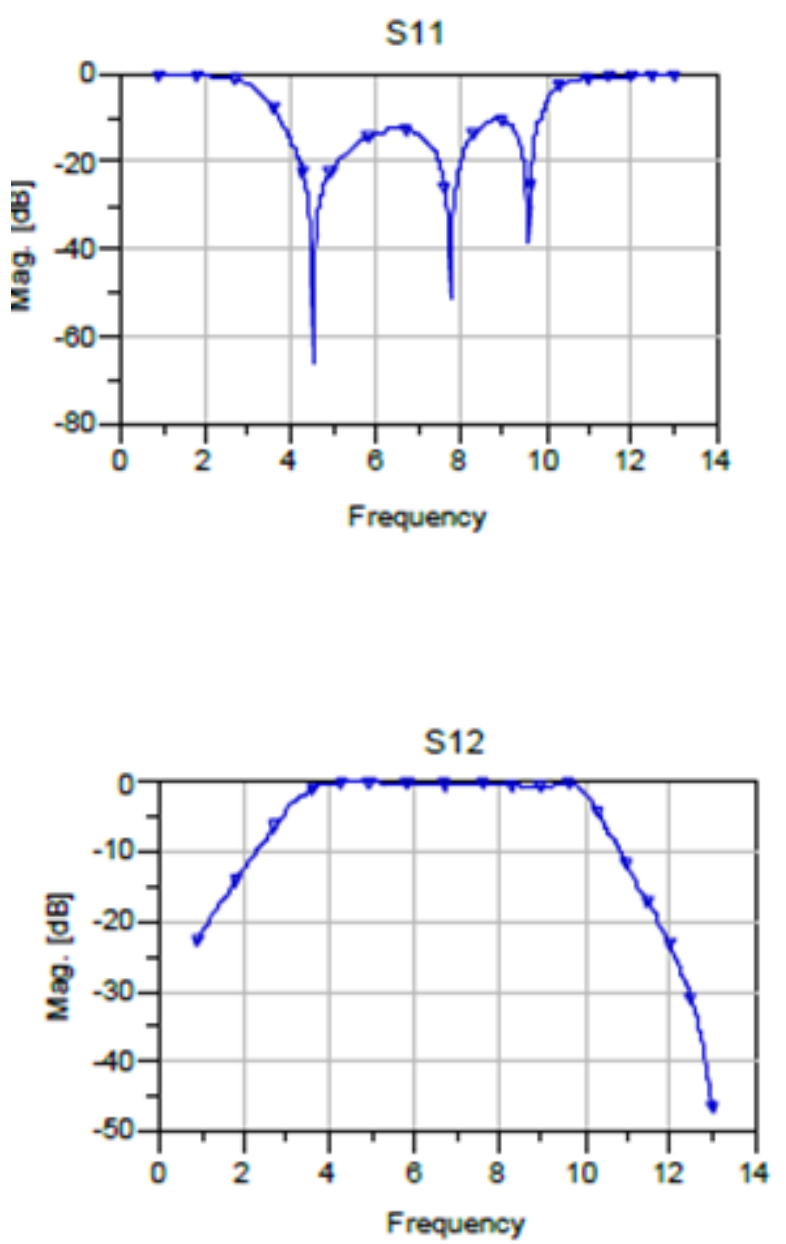

Fig 2(b).EBG Embedded MMR BPF return loss and insertion loss

\section{CONCLUSION}

The, Electromagnetic Band-hole (EBG), structures applied in planning ultra wide band BPFs shows improved pass-band in ultra wide band locale, likewise with great out-of-band dismissal in stop-band district .By utilizing this proposed the Electromagnetic Band-hole (EBG) structure channel generally size is decreased which will be appropriate for smaller remote gadgets. The outcomes been reenacted utilizing advance plan frameworks Momentum test system programming, the future work should be possible on various EBG structures and the reaction in channel plan. [7],[9] ,[11]

\section{REFERENCES}

[1] Sharma, R.K., Irusapparajan, G. \& Periyaazhagar, D. 2019 , "Three-phase symmetric cascading Z-source seven levels multilevel inverter excited by multi carrier sinusoidal pulse width modulation scheme", International Journal of Innovative Technology and Exploring Engineering, vol. 8, no. 10, pp. 4269-4274.

[2] Velavan, R., Bharanidharan, S. \& Sheeba, B. 2019, "EMF pollution Causes, effects and protection", International Journal of Innovative Technology and Exploring Engineering, vol. 8, no. 9 Special Issue 3, pp. 1166-1168.

[3] Saravana, S., Balaji, S., Arulselvi, S. \& John Paul Praveen, A. 2019 , "Reliable power quality monitoring and protection system", International Journal of Innovative Technology and Exploring Engineering, vol. 8, no. 9 Special Issue 3, pp. 644-645.

[4] Tamil Selvan, S. \& Sundararajan, M. 2019, "Performance Parameters of 3 Value 8t Cntfet Based Sram Cell Design Using H-Spice", International Journal of Recent Technology and Engineering, vol. 8, no. 2 Special issue 5, pp. 22-27.

[5] Jac Fredo, A.R., Abilash, R.S., Femi, R., Mythili, A. \& Kumar, C.S 2019, "Classification of damages in composite images using Zernike moments and support vector machines", Composites Part B: Engineering, vol. 168, pp. 77-86.

[6] Kathiravan, P. \& Govindaraju, C. 2019, "Design and evaluation of ultra gain isolated DC-DC converter for photovoltaic system", International Journal of Engineering and Advanced Technology, vol. 8, no. 5, pp. 2646-2651.

[7] Kripa, N., Vasuki, R. \& Kishore Kanna, R. 2019, "Realtime neural interface controlled au-pair BIMA bot", International Journal of Recent Technology and Engineering, vol. 8, no. 1, pp. 992-994.

[8] Mohanraj, Meenaa Kumari, M., Philomina, S. \& Jasmin, M. 2019 "In-situ humidity measurement of hydrogen fuel cell car using MEMS sensor", International Journal of Recent Technology and Engineering, vol. 8 , no. 1 , pp. $41-43$.

[9] Velmurugan, T. \& Prakash, S. 2019, "Artificial intelligent based distribution automation of swift fault detection isolation and power restoration for HT network", International Journal of Innovative Technology and Exploring Engineering, vol. 8, no. 6, pp. 1-6.

[10] Dwarakesh, K. \& Prem Kumar, G. 2019, "Five-level inverter based sequential boost system using fuzzy logic controller", International Journal of Innovative Technology and Exploring Engineering, vol. 8, no. 6, pp. 12-19.

[11] Anne Gifta, A. \& Hemavathi, G. 2019, "Analysis of grid tied solar PV system using ANFIS Algorithm", International Journal of Innovative Technology and Exploring Engineering, vol. 8, no. 6, pp. 312-316.

[12] Jayavel, R., Rangaswamy, T.R. \& Prakash, S. 2019, "Efficient grid management system with renewable and conventional power sources", International Journal of Innovative Technology and Exploring Engineering, vol. 8, no. 6, pp. 287-289.

[13] Hemavathi, G. \& Maheshwaran, S. 2019, "Proportional resonant controlled high gain step-up converter system with improved response", International Journal of Innovative Technology and Exploring Engineering, vol. 8, no. 6, pp. 317-323.

[14] Periyaazhagar, D. \& Irusapparajan, G. 2019, "Design and completion of asymmetric single phase 27 level cascaded mli for various pwm scheme", International Journal of Innovative Technology and Exploring Engineering, vol. 8, no. 6, pp. 792-797.

[15] Mahalakshmi, V. \& Vijayaragavan, S.P. 2019, "PV based power electronic converters for high voltage DC applications", International Journal of Recent Technology and Engineering, vol. 7, no. 6, pp. 670-674.

[16] Irusapparajan, G., Periyaazhagar, D., Prabaharan, N. \& Rini Ann Jerin, A. 2019, "Experimental verification of trinary DC source cascaded h-bridge multilevel inverter using

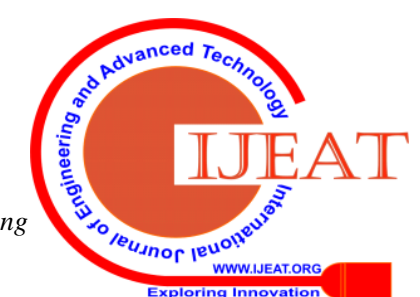


unipolar pulse width modulation", Automatika, vol. 60, no. 1, pp. 19-27.

[17] Sangeetha, G., Sherine, S., Arputharaju, K. \& Prakash, S. 2019, "On Line Monitoring of Higher Rated Alternator using Automated Generator Capability Curve Administer", Proceedings of the IEEE International Conference on \&amp;quot;Recent Trends in Electrical, Control and Communication\&amp;quot;, RTECC 2018, pp. 176.

[18] Bycil, V.J. \& Wiselin, M.C.J. 2019, "Modeling and analysis of vibration energy harvesting system using piezo stack", International Journal of Mechanical and Production Engineering Research and Development, vol. 9, no. Special Issue 1, pp. 523-533.

[19] Sripada, A., Warrier, A., Kapoor, A., Gaur, H. \& Hemalatha, B. 2018, "Dynamic lateral balance of humanoid robots on unstable surfaces", International Conference on Electrical, Electronics, Communication Computer Technologies and Optimization Techniques, ICEECCOT 2017, pp. 539.

[20] Srinivasan, S., Thirumalaivasan, K. \& Sivakumaran, T.S. 2018, "Performance evaluation of double-output luo converters", Journal of Advanced Research in Dynamical and Control Systems, vol. 10, no. 10 Special Issue, pp. 870-878.

[21] Karthikayen, A. \& Selvakumar Raja, S. 2018, "A skellam distribution inspired trust factor-based selfish node detection technique in MANETs", Journal of Advanced Research in Dynamical and Control Systems, vol. 10, no. 13, pp. 940-949.

\section{AUTHORS PROFILE}

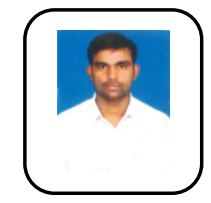

Sridhar raja D, Assistant Professor, Department of EIE,Bharath Institute of Higher education and research, Tamilnadu, India.

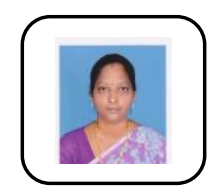

B.Kalaiselvi, Assistant Professor, Department of EIE,Bharath Institute of Higher education and research, Tamilnadu, India

T.Vijayan, Assistant Professor, Department of EIE,Bharath Institute of Higher education and research, Tamilnadu, India. 